\title{
PENGARUH MOBILITAS PENDUDUK TERHADAP BUDAYA POP DAN REMITAN MASYARAKAT DESA
}

\author{
Mars u d i \\ masjirun@yahoo.com \\ SMA Negeri 1 Lembang \\ Jl. Maribaya No. 68 Lembang Bandung Barat
}

\begin{abstract}
ABSTRAK
Terjadinya mobilitas penduduk masyarakat desa berkaitan dengan tujuan masyarakat untuk memperbaiki kesejahteraan mereka. Terjadinya mobilitas ke arah perkotaan berkaitan dengan kondisi pedesaan yang dipandang tidak mampu menopang kehidupan masyarakatnya. Selain itu kota dipandang sebagai pusat kemajuan dan pembangunan sehingga menurut mereka lebih menjanjikan dalam meningkatkan kehidupan. Selain alasan untuk mendapatkan pekerjaan yang lebih baik dan mendapatkan penghasilan yang lebih tinggi, alasan lain penduduk desa bermigrasi ke kota adalah karena untuk melanjutkan pendidikan, mengikuti suami/istri, mengikuti orang tua, atau karena diajak atau melihat teman-teman mereka yang dipandang telah berhasil di kota. Dampak-dampak dari mobilitas penduduk ini tampak dari perilaku sosial mereka, seperti budaya popular yang mereka adopsi sebagai gaya hidup dari kehidupan perkotaan, selain itu muncul budaya remitan yang memiliki dampak yang signifikan bagi kehidupan di pedesaan
\end{abstract}

Kata kunci : mobilitas penduduk, budaya pop, remitan.

\section{PENDAHULUAN}

\section{Latar Belakang}

Percepatan pembangunan perkotaan saat ini tampaknya menunjukan peningkatan yang lebih tinggi di banding dengan daerah pedesaan, hal ini berdampak pada munculnya kesenjangan dalam bidang ekonomi antara desa dan kota. Kondisi ini memicu perubahan-perubahan di masyarakat pedesaan berkaitan dengan pekerjaan, sebagain dari mereka ada yang melakukan migrasi ke kota, dan sebagian lagi tetap tinggal di pedesaan dengan bekerja atau merubah pekerjaan mereka di luar bidang pertanian karena bidang pertanian dipandang tidak dapat memberikan akselerasi dalam peningkatan perekonomian mereka. Kenyataan lain yang terjadi saat ini adalah pertumbuhan penduduk di pedesaan tidak sejalan dengan pertumbuhan perekonomiannya, sehingga kesempatan kerja di pedesaan kecil, hal inilah yang menyebabkan penduduk pergi keluar desa terutama ke kota untuk mencari pekerjaan tetap atau sementara.

Saat ini tampak terjadi perubahan sosial ekonomi di masyarakat pedesaan khususnya di pulau Jawa sebagai akibat dari mobiltas masyarakatnya terutama ke daerah perkotaan. Mereka memandang bahwa kota adalah pusat kemajuan dan pembangunan, kota dianggap sebagai daerah yang penuh kemajuan dan desa yang 
dianggap sebagai daerah yang terbelakang dan belum maju. Hal inilah yang menjadikan daya tarik daerah perkotaan sehingga membuat penduduk daerah pedesaan berduyun-duyun datang ke kota yang menurut mereka menjanjikan kehidupan yang lebih baik.

Selain alasan untuk mendapatkan pekerjaan yang lebih baik dan mendapatkan penghasilan yang lebih tinggi, alasan lain penduduk desa bermigrasi ke kota adalah karena untuk melanjutkan pendidikan, mengikuti suami/istri, mengikuti orang tua, atau karena diajak atau melihat teman-teman mereka yang dipandang telah berhasil di kota. Secha Alatas, Suharso dan Munir (dalam Maria Sri Rahayu, 2007) mengatakan bahwa faktor ekonomi merupakan motif utama masyarakat mengadakan mobilitas atau migrasi. Motif tersebut selain sebagai pertimbangan ekonomi yang rasional juga disebabkan karena mobilitas ke perkotaan yang telah mereka lakukan mempunyai dua harapan yaitu untuk memperoleh pekerjaan dan harapan untuk memperoleh pendapatan yang lebih tinggi daripada yang diperoleh di pedesaan.

Umumnya migrasi penduduk mengarah pada wilayah yang "subur" pembangunan ekonominya, karena faktor ekonomi sangat kental mempengaruhi orang untuk pindah. Hal ini dipertegas lagi oleh Tommy Firman (1994), bahwa migrasi sebenarnya merupakan suatu reaksi atas kesempatan ekonomi pada suatu wilayah. Pola migrasi di negara-negara yang telah berkembang biasanya sangat rumit (kompleks) menggambarkan kesempatan ekonomi yang lebih seimbang dan saling ketergantungan antar wilayah di dalamnya. Sebaliknya di negara-negara berkembang biasanya pola migrasi menunjukkan pemusatan arus migrasi ke daerah-daerah tertentu saja, khususnya kota-kota besar.

Bagi sebagian masyarakat, mobilitas penduduk merupakan salah satu strategi bagi rumah tangga pedesaan untuk memperbaiki kesejahteraan serta mendapatkan dan menaikkan penghasilan mereka, namun demikian disamping kemudian mengalirkan nilai balikan ekonomi ke pedesaan, sesungguhnya mereka juga meninggalkan banyak persoalan berupa perubahan sosial yang tidak selalu berdimensi positif di desa asal mereka. Perubahan-perubahan sosial ini diantaranya adalah berkaiatan dengan gaya hidup masyarakat.

\section{Tujuan}

Adapun tujuan penulisan artikel ini adalah untuk mengidentifikasi dan menganalisis faktor-faktor mobilitas penduduk yang berpengaruh terhadap budaya pop dan remitan pada masyarakat desa.

\section{HASIL DAN PEMBAHASAN}

\section{Budaya Popular (Popular Culture) Masyarakat Desa Sebagai Dampak Mobilitas Penduduk}

Untuk membahas pengertian Budaya Pop (Popular Culture) ada baiknya kita pahami dulu tentang kata "budaya", dan "populer". Budaya dapat didefinisikan sebagai berikut, 
"Culture can be defined as all the ways of life including arts, beliefs and institutions of a population that are passed down from generation to generation. Culture has been called "the way of life for an entire society. As such, it includes codes of manners, dress, language, religion, rituals, norms of behavior such as law and morality, and systems of belief as well as the art". (http://en.wikipedia.org/wiki/Culture)

Selanjutnya, definisi budaya juga disebutkan sebagai: 1)The totality of socially transmitted behavior patterns, arts, beliefs, institutions, and all other products of human work and thought; 2) These patterns, traits, and products considered as the expression of a particular period, class, community, or population; 3) The predominating attitudes and behavior that characterize the functioning of a group or organization; 4) Intellectual and artistic activity and the works produced by it. (http://xroads.virginia.edu/ YP/yppop.html\#Circuses)

Dari definisi-definisi di atas dapat disimpulkan bahwa budaya merupakan produk pemikiran dan pemahaman manusia yang kemudian menjadi ways of life yang bergulir dari generasi ke generasi selanjutnya. Produk pemikiran ini kemudian diterjemahkan dalam bentuk simbol-simbol dan kode (tanda), misalnya saja, kode berprilaku, berpakaian, berbahasa, beragama dan ritual-ritual (upacara) lainnya.

Popular dapat didefinisikan sebagai berikut : 1) Of, pertaining to, or consisting of the common people, or the people as a whole as distinguished from any particular class; constituted or carried on by the people; 2) Having characteristics attributed to the common people; low, vulgar, plebeian. Obs.; 3) Intended for or suited to ordinary people. a. Adapted to the understanding or taste of ordinary people. (http://xroads.virginia.edu/ YP/yppop.html\#Circuses). Dengan demikian, popular adalah sesuatu yang berkaitan dengan orang kebanyakan atau manusia pada umumnya (common people). Gambaran di atas menunjukkan pula bahwa sesuatu itu diterima secara luas ditengah-tengah masyarakat.

Pengertian popular culture seperti yang termuat dalam situs wikipedia adalah berikut ini :

"...This is seen as a commercial culture, mass produced for mass consumption. From a U.K. (and European) point of view, this may be equated to American culture. Alternatively, "pop culture" can be defined as an "authentic" culture of the people, but this can be problematic because there are many ways of defining the "people."

Dari definisi tersebut, tampaknya ada keterkaitan erat antara popular culture dengan commercial culture (budaya komersil). Sesuatu sengaja diproduksi untuk konsumsi yang sifatnya massal (common people). Bisa dikatakan bahwa sesuatu itu diproduksi hanya berlandaskan keinginan pasar saja. Dengan demikian, budaya popular hanya akan terjadi manakala keinginan pasar menjadi perhatian sentral.

Popular Culture sangat erat kaitannya dengan media massa. Jika media melemparkan pesan ketengah-tengah masyarakat (audience) melalui televisi misalnya dan kemudian masyarakat luas menyukainya, maka pesan itupun akan diperbanyak produksinya. Jika pesan yang kemudian disukai khalayak ramai itu adalah berupa entertaintment, gosip, kisah hidup selebritis, bahkan film-film yang 
beraroma kekerasan, maka itulah gambaran atau cermin budaya yang ada ditengah-tengah masyarakat.

Keberadaan media memang tidak mungkin dilepaskan dari kepentingan pasar. Dengan demikian, kalau masyarakat tidak mampu bersikap selektif terhadap pesan media, maka akan menjadi korban media. Tidak salah memang ketika masyarakat membeli sebuah produk atau aksesoris gaya hidup berdasarkan informasi dari media. Namun, yang perlu diingat, sebelumnya harus mempertimbangkan seberapa perlu produk yang dibeli itu. Apakah memang membutuhkan produk itu ataukah hanya karena terpengaruh oleh iming-iming media, sehingga barang tidak lagi hanya dikonsumsi karena kebutuhan, melainkan sudah bergeser menjadi sekedar mengikuti trend gaya hidup, menunjukkan image tertentu, ataupun hanya untuk kesenangan pribadi.

Popular Cultur memiliki keterkaitan yang sangat erat dengan mobilitas dan pengaruh kota terhadap masayarakat desa. Secara ekonomi di desa terjadi peningkatan dan kemajuan. Hal itu bisa terlihat dengan terjaminnya kehidupan ekonomi mereka dan secara fisik terlihat dari kondisi rumah mereka beserta perabotan yang ada di dalamnya. Bentuk-bentuk rumah semakin bagus dan Perabotan yang ada di rumah juga cukup lengkap misalnya bufet, sofa, almari, tv, radio, telepon, kipas angin, antena parabola, bahkan untuk peralatan kendaraan bermotor misalnya itu bukan hal yang baru lagi. Banyak diantara mereka yang sudah mempunyai kendaraan roda empat. Selain itu, juga juga berdampak pada kemajuan desa karena pada kenyataannya mereka juga menyumbangkan untuk keperluan pembangunan desa. Besarnya sumbangan untuk pembangunan desa memang sulit diukur secara statistik tetapi tampak nyata pada pembangunan sarana-sarana fisik di desa. Pembangunan balai desa, jalan raya desa, gang, perbaikan got, perbaikan gedung pos kamling, dll. (Maria Sri Rahayu, 2007).

Peningkatan perekonomian penduduk berpengaruh juga dalam hal perilaku sosial dalam masyarakat. Masyarakat terlihat lebih konsumtif dan materialistis apalagi hal itu lebih sering dikaitkan dengan "simbol status" dan "prestise sosial" yang ingin diraihnya. Mereka beranggapan salah satu simbol keberhasilan dalam berusaha adalah rumah, sehingga dalam membangun rumah terkesan saling berlomba dan berusaha semewah mungkin padahal tidak jarang rumah banyak yang dtinggalkan kosong sementara mereka berusaha di kota. Mereka berusaha membanting tulang di kota tanpa menikmati kenyamanan, kemewahan, dan kemegahan rumahnya secara utuh yang merupakan hasil kerja keras mereka.

Perubahan gaya hidup konsumtif dan suka pamer nampak juga pada saat di desa sedang ada acara dan saat lebaran. Pada saat inilah terlihat berbagai macam gaya busana dan berbagai macam perhiasan yang terutama dipakai oleh para ibu dan remaja putri. Demikian juga dengan perilaku para pemuda yang semakin jauh dari kesan "sopan". Mereka banyak yang mulai berani kebut-kebutan di jalan desa dan adanya kebiasaan minuman keras dan menegak pil "koplo".

Perubahan gaya hidup ini juga sangat tampak di kalangan remaja pedesaan. Perkembangan media dan teknologi informasi memudahkan masuknya pengaruh gaya hidup global ke desa melalui media yang mereka lihat, baca dan dengar sehingga mempengaruhi gaya hidup remaja desa saat ini. Yang akhirnya mereka tiru dan ikuti sebagai usaha untuk mengaktualisasikan identitas dirinya seperti 
yang ada di media tersebut. Media informasi menciptakan citra diri sebagai bagian kehidupan remaja ideal yang umumnya menginformasikan berbagai tata cara bergaul maupun perlengkapan hobi yang relevan bagi remaja. Sampai aksesoris yang cocok digunakan dalam berbagai kesempatan, merupakan informasi yang dianggap layak berita, atau cerita para idola remaja yang mendominasi dunia hiburan yang gaya hidupnya sering mereka tiru. Mereka yang gemar mengikuti trend berpakaian ala remaja kota yang mereka ikuti dari tokoh idolanya di televisi dan majalah remaja biasanya juga suka mengganti-ganti model rambutnya sesuai dengan model rambut tokoh idolanya tersebut seperti di Shagy, Rebonding, dan warna.

Model pakaian yang disukai umumnya adalah pakaian yang nyaman untuk dipakai, modis, dan trendy sebagai simbol bahwa seseorang lebih mengikuti perkembangan zaman dibanding yang lain. Gaya berpakaian tersebut disukai karena terpengaruh oleh teman, mengikuti trend yang ada di media supaya dibilang anak gaul, serta alasan kenyamanan dalam berpakaian. Ada juga yang menyatakan bahwa mereka menyukai pakaian yang mengikuti trend dari Barat yang dilihat melalui media dan iklan.

Lebih lanjut lagi, konsumsi terhadap suatu barang, menurut Weber (1922), merupakan gambaran gaya hidup tertentu dari kelompok status tertentu. Konsumsi terhadap barang merupakan landasan bagi penjenjangan dari kelompok status. Dengan mengkonsumsi gaya atau simbol-simbol tertentu mereka merasa sudah menjadi kelompok anak muda metropolitan yang modern. Saat ini, konsumsi dipandang dalam sosiologi bukan lagi hanya sebagai sekadar pemenuhan yang bersifat fisik dan biologis manusia, tetapi berkait kepada aspek-aspek sosial budaya. Konsumsi berhubungan dengan masalah selera, identitas, atau gaya hidup. Selera itu sendiri adalah sesuatu yang dapat berubah, difokuskan pada kualitas simbolik dari barang, dan tergantung pada persepsi tentang selera dari orang lain.

\section{Mobilitas Penduduk Desa dan Budaya Remitan}

Remitan menurut Curson (1981) merupakan pengiriman uang, barang, ide-ide pembangunan dari perkotaan ke pedesaan dan merupakan instrumen penting dalam kehidupan sosial ekonomi suatu masyarakat. Dari segi ekonomi keberadaan remitan sangatlah penting karena mampu meningkatkan ekonomi keluarga dan juga untuk kemajuan bagi masyarakat penerimanya. Menurut Connel (1980), di negara-negara sedang berkembang terdapat hubungan yang sangat erat antara migran dengan daerah asalnya, dan hal tersebutlah yang memunculkan fenomena remitan. Di samping sebagai salah satu instrumen perubahan ekonomi, remitan juga mempunyai dampak yang luas dalam kehidupan sosial maupun budaya bagi keluarga, masyarakat penerima dan daerah asalnya.

Remitan dalam konteks migrasi di negara-negara sedang berkembang merupakan bentuk upaya migran dalam menjaga kelangsungan ikatan sosial ekonomi dengan daerah asal, meskipun secara geografis mereka terpisah jauh. Selain itu, migran mengirim remitan karena secara moral maupun sosial mereka memiliki tanggung jawab terhadap keluarga yang ditinggalkan (Curson,1983). Kewajiban dan tanggung jawab sebagai seorang migran, sudah ditanamkan sejak 
masih kanak-kanak. Masyarakat akan menghargai migran yang secara rutin mengirim remitan ke daerah asal, dan sebaliknya akan merendahkan migran yang tidak bisa memenuhi kewajiban dan tanggung jawabnya.

Dalam perspektif yang lebih luas, remitan dari migran dipandang sebagai suatu instrumen dalam memperbaiki keseimbangan pembayaran, dan merangsang tabungan dan investasi di daerah asal. Oleh karenanya dapat dikemukakan bahwa remitan menjadi komponen penting dalam mengkaitkan mobilitas pekerja dengan proses pembangunan di daerah asal. Selain itu, migran mengirim remitan karena secara moral maupun sosial mereka memiliki tanggung jawab terhadap keluarga yang ditinggalkan (Curson,1983). Kewajiban dan tanggung jawab sebagai seorang migran, sudah ditanamkan sejak masih kanak-kanak. Masyarakat akan menghargai migran yang secara rutin mengirim remitan ke daerah asal, dan sebaliknya akan merendahkan migran yang tidak bisa memenuhi kewajiban dan tanggung jawabnya.

Hal tersebut didukung oleh penelitian yang dilakukan di daerah Jatinom Jawa Tengah (Effendi, 1993). Sejak pertengahan tahun 1980an, seiring dengan meningkatnya mobilitas pekerja, terjadi perubahan pola makanan keluarga migran di daerah asal menuju pada pola makanan dengan gizi sehat. Perubahan ini tidak dapat dilepaskan dari peningkatan daya beli keluarga migran di daerah asal, sebagai akibat adanya remitan. Senada dengan hasol penelitian Maria Sri Rhayu (2007) pada masyarakat Desa Cawaban Tegal Jawa Tengah yang sebagian besar penduduknya adalah pedagang warteg di Jakarta. Pada kehidupan pedagang warteg masyarakat desa Cabawan, remitan yang dikirim karena pada dasarnya antara keluarga yang ada di kota dan di desa merupakan satu kesatuan ekonomi. Remitan atau yang lazim mereka sebut "kiriman" selain ditujukan untuk keluarganya juga ditujukan untuk anggota masyarakat desanya dan juga untuk keperluan desa asalnya.

Peningkatan daya beli tidak hanya berpengaruh pada pola makanan, namun juga berpengaruh pada kemampuan membeli barang-barang konsumsi rumah tangga lainnya, seperti pakaian, sepatu, alat-alat dapur, radio, televisi dan sepeda motor. Permintaan akan barang-barang tersebut telah memunculkan peluang berusaha di sektor perdagangan, dan pada tahap selanjutnya berefek ganda pada peluang berusaha di sektor lainnya.

Namun di sisi lain, remitan ternyata tidak hanya mempengaruhi pola konsumsi keluarga migran di daerah asal. Dalam kerangka pemupukan remitan, migran berusaha melakukan berbagai kompromi untuk mengalokasikan sumberdaya yang dimilikinya, dan mengadopsi pola konsumsi tersendiri di daerah tujuan.

Para migran akan melakukan "pengorbanan" dalam hal makanan, pakaian, dan perumahan supaya bisa menabung dan akhirnya bisa mengirim remitan ke daerah asal. Secara sederhana para migran akan meminimalkan pengeluaran untuk memaksimalkan pendapatan. Migran yang berpendapatan rendah dan tenaga kerja tidak terampil, akan mencari rumah yang paling murah dan biasanya merupakan pemukiman miskin di pusat-pusat kota.

Berbagai pemikiran dan hasil penelitian telah menemukan keberagaman tujuan remitan ini, namun demikian dapat dikelompokkan atas tujuan-tujuan sebagai berikut: 
a. Kebutuhan hidup sehari-hari keluarga.

Sejumlah besar remitan yang dikirim oleh migran berfungsi untuk menyokong kerabat/keluarga migran yang ada di daerah asal. Migran mempunyai kewajiban dan tanggung jawab untuk mengirimkan uang/barang untuk menyokong biaya hidup sehari- hari dari kerabat dan keluarganya, terutama untuk anak-anak dan orang tua.

b. Peringatan hari-hari besar yang berhubungan dengan siklus hidup manusia

Di samping mempunyai tanggung jawab terhadap kebutuhan hidup sehari-hari keluarga dan kerabatnya, seorang migran juga berusaha untuk dapat pulang ke daerah asal pada saat diadakan peringatan hari-hari besar yang berhubungan dengan siklus hidup manusia, misalnya kelahiran, perkawinan, dan kematian. Menurut Curson (1983) pada saat itulah, jumlah remitan yang dikirim atau ditinggalkan lebih besar daripada hari-hari biasa.

c. Investasi

Bentuk investasi adalah perbaikan dan pembangunan perumahan, membeli tanah, mendirikan industri kecil, dan lain-lainnya. Kegiatan ini tidak hanya bersifat ekonomi, tetapi juga sebagai sarana sosial dan budaya dalam menjaga kelangsungan hidup di daerah asal, tetapi juga bersifat psikologis, karena erat hubungannya dengan prestise seseorang. Effendi (1993) dalam penelitiannya di tiga desa Jatinom, Klaten menemukan bahwa remitan telah digunakan untuk modal usaha pada usaha-usaha skala kecil seperti pertanian jeruk, peternakan ayam, perdangan dan bengkel sepeda.

d. Jaminan hari tua

Migran mempunyai keinginan, jika mereka mempunyai cukup uang atau sudah pensiun, mereka akan kembali ke daerah asal. Hal ini erat kaitannya dengan fungsi investasi, mereka akan membangun rumah atau membeli tanah di daerah asal sebagai simbol kesejahteraan, prestisius, dan kesuksesan di daerah rantau. Lee (1992) mengemukakan bahwa berbagai pengalaman baru yang diperoleh di tempat tujuan, apakah itu keterampilan khusus atau kekayaan, sering dapat menyebabkan orang kembali ke tempat asal dengan posisi yang lebih menguntungkan. Selain itu, tidak semua yang bermigrasi bermaksud menetap selama- lamanya di tempat tujuan

\section{Peningkatan Jumlah Migrasi}

Peningkatan status ekonomi para migran berdampak pada peningkatan migrasi. Hal ini karena mereka tergiur oleh kesuksesan dan kemewahan yang dicapai oleh teman-temannya. Tenaga kerja produktif di desa semakin berkurang karena rata-rata penduduk yang melakukan urbanisasi adalah mereka yang berusia produktif dalam arti tenaganya masih sangat potensial untuk menjalankan pekerjaan di daerah asal.

Banyaknya tenaga potensial yang terserap dalam ekonomi perkotaan menyebabkan desa kekurangan tenaga produktif karena rata-rata mereka yang tinggal di desa berusian 60 tahun ke atas dan anak-anak usia sekolah. Fenomena migrasi masyarakat desa ke kota menjadi upaya yang sering ditempuh oleh masyarakat desa yang merasa kesulitan meningkatkan kesejahteraan ekonominya. Migrasi menjadi upaya alternatif bagi masyarakat desa untuk mencari pekerjaan 
ke kota karena tertutupnya peluang mencari pekerjaan di desa yang dipandang tidak dapat menjanjikan. Meskipun hal ini mengandung resiko-resiko sosial, psikologi, ekonomi dan lain-lain, kesenjangan kesejahteraan desa-kota yang begitu drastis lebih menyingkirkan pertimbangan-pertimbangan atas dasar resikoresiko tersebut.

\section{SIMPULAN}

Kesenjangan tingkat kesejahteraan antara desa dengan kota telah menjadi faktor pendorong terjadinya mobilitas masyarakat desa ke kota. Dari sisi ekonomi, kota yang dipandang lebih sejahtera daripada desa telah mendorong orang desa melakukan migrasi ke kota untuk meningkatkan kesejahtraannya. Pabrik modern dan peluang adanya lapangan kerja di kota telah menanamkan harapan baru bagi masyarakat desa untuk dapat meningkatkan kesejahteraannya. Alasan ekonomi menjadi alasan yang dominan.

Bagi masyarakat desa fenomena migrasi telah membawa dampak baik yang bersifat positif maupun negatif. Bersifat positif karena secara fisik dapat membantu pelaksanaan pembangunan dan peningkatan pendidikan dengan kemampuan ekonomi yang dimiliki. Sedangkan dampak negatifnya adalah terjadinya proses pemaksaan perilaku kehidupan kota di desa yang seringkali tidak sesuai dengan nilai-nilai yang hidup di desa. Terlepas dari dampak yang ditimbulkannya, fenomena ini merupakan dampak dari penerapan pembangunan dengan pendekatan/paradigma pertumbuhan yang berpusat pada kota-kota besar. Karena pertumbuhan dirasa tidak dapat menetes ke wilayah pedesaan maka orangorang desalah yang harus menjemput pembagian hasil pembangunan dengan datang ke kota. Dengan cara demikianlah hasil pembangunan dapat didistribusikan ke wilayah-wilayah desa.

\section{DAFTAR PUSTAKA}

Biro Pusat Statistik. (1995). Estimasi Fertilitas, Mortalitas dan Migrasi, Hasil Survei Penduduk Antara Sensus. Jakarta: BPS.

Dep. P dan K. (1992). Dampak Urbanisasi Terhadap Pola Kegiatan Ekonomi Pedesaaan Indramayu (Proyek Penelitian dan Pembinaan Nilai-Nilai Budaya). Jakarta: Dep. P\&K.

Hanafiah, T. (1982). Pendekatan Wilayah Terhadap Masalah Pembangunan Pedesaan. Bogor: Fakultas Pertanian IPB.

Ibrahim, Idi Subandy. (1997). Ecstasy Gaya Hidup, Kebudayaan Pop dalam Masyarakat Komoditas Indonesia. Bandung: Mizan.

Koentjaraningrat. (1985). Kebudayaan Mentalitet dan Pembangunan. Jakarta : Gramedia.

Koentjaraningrat. (1981). Pengantar Antropologi. Jakarta: Gramedia.

Rita Rahmawati, (2008). Pertumbuhan, Komposisi dan Distribusi Penduduk dan Kaitannya Dengan Pembangunan Berkelanjutan dan Berwawasan Lingkungan di Indonesia. Bogor: Departemen KPM FEMA IPB. 
Soekanto, S. (1994). Sosiologi Suatu Pengantar. Jakarta: Raja Grafindo Persada.

Rini, Jacinta. (2010). Mencemaskan Penampilan. [Online]. Tersedia: http://www.e-psikologi.com/REMAJA/110604.htm.[15Oktober 2010].

Tambunan, Raymond. (2010). Konsumerisme dan Gaya Hidup Remaja. [Online]. Tersedia:http://www.epsikologi. com/remaja.[15 Oktober 2010]

Wilodati. (2010). Tuntutan Mobilitas Horizontal/Geografis yang berakibat Kurang Teratur dan Intensifnya Kontak Antar Keluarga Sebagai Salah Satu Faktor Penyebab Disorganisasi Keluarga Tradisional Pada Masyarakat [Online].

Tersedia: http://file.upi.edu/ai.php?dir=Direktori/B\%20-\%20FPIPS/...pdf.[16 Oktober 2010] 